\title{
(Nie)przekładalność języków. Analiza korpusowa opinii sądowo- psychiatrycznych
}

\author{
Agnieszka Karlińska \\ Uniwersytet Warszawski
}

DOI: http://dx.doi.org/10.18778/1733-8069.16.4.06

Słowa kluczowe: psychiatria sądowa, opinie sądowopsychiatryczne, analiza korpusowa, analiza słów kluczowych, analiza konkordancji

\begin{abstract}
Abstrakt: W artykule przedstawione zostały wyzwania, z jakimi mierzą się psychiatrzy, wkraczając w obszar wymiaru sprawiedliwości. Na podstawie analizy 65 opinii sądowo-psychiatrycznych zrekonstruowano strategie uzgadniania języka prawa i języka medycyny przyjmowane przez biegłych. Zastosowano metody i narzędzia lingwistyki korpusowej: listy frekwencyjne, analizę słów kluczowych oraz analizę konkordancji. Uzyskane wyniki wskazują, że psychiatrzy sądowi mają trudności z dokonaniem przekładu z języka medycyny na język prawa. Posługują się leksyką i strukturami językowymi właściwymi dla gatunków medycznych, a słownictwo prawne przejmują w postaci związków wyrazowych zaczerpniętych z kodeksu karnego. Wprowadzając terminy prawne, próbują wypełnić je aktualną wiedzą medyczną. Napięcia wynikające ze zderzenia dyskursu prawnego i psychiatrycznego opisane zostały w kategoriach zderzenia dwóch logik: „albo, albo”, właściwej dla systemu sprawiedliwości, oraz „zarówno, jak też”, przyjmowanej we współczesnej psychiatrii klinicznej. $\mathrm{W}$ analizie uchwycone zostały także wyzwania etyczne związane z występowaniem przez psychiatrów sądowych w podwójnej roli - lekarzy i reprezentantów wymiaru sprawiedliwości. Wykazała ona, że biegli skupiali się na realizacji drugiej z tych ról, sytuując się po stronie prawa.
\end{abstract}

Agnieszka Karlińska, absolwentka socjologii, filologii polskiej i kulturoznawstwa w ramach Międzywydziałowych Indywidualnych Studiów Humanistycznych Uniwersytetu Warszawskiego, asystentka na Wydziale „Artes Liberales", doktorantka w Instytucie Literatury Polskiej UW. Bada rolę psychiatrów w procesie sądowym i język psychiatrii sądowej. Interesuje się zagadnieniami z za- kresu socjologii prawa, socjologii literatury oraz analizy tekstu.
Adres kontaktowy:
Wydział „Artes Liberales” UW
ul. Nowy Świat 69, 00-046 Warszawa
e-mail: a.karlinska@uw.edu.pl 


\section{W}

piśmiennictwie prawnym i psychiatrycznym za podstawowe zadanie psychiatrów sądowych uznaje się przełożenie wniosków o charakterze medycznym na wyjaśnienia i interpretacje czytelne dla społeczności prawnej i możliwe do wykorzystania w czynnościach procesowych (O'Grady 2004). Rola biegłego porównywana jest często do roli tłumacza lub ambasadora (Resnick, Soliman 2011). Zwolennicy tych porównań podkreślają, że psychiatra sądowy swoje teksty kieruje do publiczności o odmiennym wykształceniu, kulturze dyscyplinarnej i języku zawodowym (Griffith, Baranoski 2007; Griffith, Stankovic, Baranoski 2010; 2011). Zauważają, że opinie sądowo-psychiatryczne mogą trafić do szerszego grona odbiorców, również spoza obszaru prawa (dziennikarzy, a za ich sprawą do opinii publicznej), którzy będą w nich szukać wyjaśnienia motywów zbrodni i osobowości sprawcy. Biegły uwikłany jest tym samym w szereg, niekiedy sprzecznych ze sobą, narracji $-\mathrm{w}$ „narracje prawa, polityki, aktualnych postaw społecznych, mediów, nauk medycznych i behawioralnych, a także zawodu, który wykonuje" (Mullen 2010: 169 [tłum. własne]).

Szerszego kontekstu do analizy związków między psychiatrią i prawem dostarczają prace Michela Foucaulta (1993), który system medyczny traktował jako dopełnienie czy też przedłużenie systemu penalnego. Włączenie ekspertyz biegłych w obręb wymiaru sprawiedliwości oznaczało jego zdaniem wprowadzenie oceny normalności oraz możliwości odesłania oskarżonych „równocześnie do technologii penalnej - więzienia - i do technologii medycznej, jeśli nie do szpitala psychiatrycznego, to przynajmniej pod nadzór kuratora" (Foucault 1988: 313). Rolą specjalistów zdrowia psychicznego miała być ochrona społeczeństwa przed tym, co anormalne i niebezpieczne, a psychiatria, uwikłana w struktury władzy, funkcjonowała jako narzędzie kontroli społecznej. Inaczej zadania psychiatrów sądowych zdefiniować można, korzystając z kategorii zaproponowanych między innymi przez Luca Boltanskiego (2014). W tym ujęciu, poprzez opisanie przestępstwa w języku psychopatologii, psychiatrzy - podobnie jak opisywani przez francuskiego socjologa detektywi - nadają znaczenie zjawiskom wykraczającym poza przyjęte ramy prawne, polityczne czy moralne, naruszającym reguły życia zbiorowego i jawiącym się jako irracjonalne (zob. Verde i in. 2006; Griffith i in. 2010). Rola psychiatrów polega na dostarczaniu wyjaśnień i uczynieniu zbrodni - a więc zjawiska, które narusza reguły życia zbiorowego, wiąże się z lękiem i niepewnością - zrozumiałą. Pozwala to na odbudowanie poczucia bezpieczeństwa i przywrócenie porządku.

Niezależnie od tego, którą z tych perspektyw przyjmiemy, jasne staje się, że - wbrew przekonaniom części środowiska (np. Giorgi-Guarnieri i in. 2002) - opinie sądowo-psychiatryczne nie stanowią obiektywnych, bezosobowych produktów pracy biegłych. Foucault (2002), odnosząc się do sprawy Pierre'a Rivière'a, wskazywał, że jedną z przyczyn rozbieżności diagnostycznych $\mathrm{w}$ ekspertyzach psychiatrycznych jest kierowanie się przez biegłych różnymi wariantami wiedzy medycznej, proceduralnej i potocznej. Prowadzi to do wydobywania lub pomijania $\mathrm{w}$ procesie formułowania opinii określonych faktów, dzięki czemu działania przestępcze zyskują zupełnie inny kontekst. Do podobnych wniosków doszli autorzy zajmujący się rolą narracji w rekonceptualizacji założeń etycznych leżących u podstaw oceny sądowo-psychiatrycznej (Candilis, Martinez, Dording 2001; Martinez, Candilis 2005, Candilis, Weinstock, Martinez 2007; Griffith, Baranoski 2007; Candilis 2009; Griffith i in. 2010; 2011). Przekonywali 
oni, że opinie nie są tekstami bezstronnymi, a obecność głosu odautorskiego (wprowadzonego świadomie lub nie) jest $\mathrm{w}$ nich nieunikniona. Zgodnie z tym podejściem proces opracowywania ekspertyz ma charakter performatywny i nie polega jedynie na przedstawieniu ustaleń klinicznych, ale na tworzeniu narracji o czynie i jego sprawcy. Zadaniem psychiatry sądowego jest umieszczenie w ramach fabuły tekstów powstałych $\mathrm{w}$ trakcie dochodzenia (m.in. protokołów policyjnych, transkrypcji przesłuchań świadków czy opinii innych biegłych), a więc zbieranie i łączenie różnych głosów. Psychiatra musi je uporządkować, stworzyć syntezę i zaproponować własną narrację. W tym rozumieniu ekspertyzy stanowią mieszaninę nauki i literatury i mogą być analizowane przy użyciu narzędzi filologicznych.

Rozwój podejścia narracyjnego nie doprowadził do podjęcia systematycznych badań nad językiem psychiatrii sądowej. Choć praktyki medyczna i prawna są coraz częściej analizowane jako praktyki dyskursywne (zob. Van Leeuwen, Kimsma 1997; Galdia 2017), a dyskurs sądowy był przedmiotem badań prowadzonych zarówno z pozycji lingwistycznych (np. Bhatia 1987; Rzeszutko 2003; Heffer 2005), jak i socjologicznych (np. Garfinkel 1967; Atkinson, Drew 1979; Matoesian 1993), brakuje badań, które próbowałyby odpowiedzieć na pytanie, w jaki sposób przypadki psychiatryczne są rekontekstualizowane $\mathrm{w}$ otoczeniu prawnym na poziomie językowym.

W artykule zidentyfikuję napięcia wynikające z konieczności uzgadniania języka medyczno-psychologicznego z językiem prawa w polskim wymiarze sprawiedliwości. Na podstawie analizy korpusowej opinii sądowo-psychiatrycznych wydanych w referencyjnym ośrodku orzecznictwa psychiatrycznego w Polsce dokonam rekonstrukcji procesu przecho- dzenia od ustaleń medycznych do wniosków dotyczących normy prawnej i pokażę, jakie strategie komunikacyjne przyjmują psychiatrzy, tworząc teksty dla odbiorców z obszaru prawa. Będzie to pierwsza analiza tego rodzaju materiału z użyciem metod wypracowanych na gruncie językoznawstwa korpusowego. Zanim przejdę do omówienia procesu tworzenia korpusu i zastosowanych metod badawczych, przedstawię wyzwania, z jakimi mierzą się psychiatrzy, wkraczając w obszar wymiaru sprawiedliwości. Na tak zarysowanym tle zrekonstruuję sposoby uzgadniania języka prawa i języka medycyny.

\section{Psychiatria na wokandzie}

Proces przekładu z języka psychiatrii na język prawa wiąże się z wyzwaniami o charakterze metodologicznym, etycznym, instytucjonalnym i dyscyplinarnym. Po pierwsze, opiniowanie na potrzeby sądu wymaga od psychiatrów znajomości specyficznej metodologii, odmiennej od tej, jakiej używają w codziennej praktyce lekarskiej. Ocena stanu psychicznego oskarżonego lub podejrzanej wymaga uzyskania większej niż w warunkach klinicznych trafności i pewności diagnozy, poszerzenia materiału dowodowego w celu ustalenia stanu psychicznego tempore criminis, a także uwzględnienia możliwości symulacji i agrawacji objawów (Pobocha 2010; 2013).

Po drugie, biegły odgrywa rolę „podwójnego agenta" (Stone 1984; zob. też O'Grady 2004). Z jednej strony jest lekarzem, który powinien kierować się wyłącznie interesem pacjenta, z drugiej zaś występuje jako reprezentant wymiaru sprawiedliwości, który musi troszczyć się przede wszystkim o dobro społeczne. Medycyna i prawo mają różne cele i posługują się odmiennymi ramami etycznymi (Candilis 2009; zob. też Applebaum 1997). Ponieważ 
celem prawa jest wymierzenie sprawiedliwości, jego system etyczny jest skoncentrowany na utrzymaniu porządku społecznego, nawet kosztem jednostki. Dla psychiatrii, ufundowanej na wartościach opieki i leczenia, podstawowymi zasadami są natomiast dobro pacjenta i nieszkodzenie (Candilis i in. 2007).

Po trzecie, współpraca pomiędzy organami procesowymi a biegłymi wykracza poza tradycyjną formę, w której psychiatra jest ekspertem, dysponującym wiedzą specjalną, niezbędną do rozstrzygnięcia konkretnego problemu prawnego (Gierowski 2014). Granice pomiędzy oceną medyczną a oceną prawną ulegają zatarciu (zob. Buchanan 2006; Meynen 2016). Biegli dokonują często nie tylko diagnozy, ale także interpretacji czynu zabronionego, na przykład $\mathrm{w}$ zakresie kwalifikacji prawnej. Z drugiej strony organy procesowe mają tendencję do bezkrytycznego przyjmowania wniosków lekarzy (Paprzycki 2011). W efekcie sąd jedynie wymierza karę, a o poczytalności rozstrzygają biegli, którzy uzyskują tym samym status „sędziów naukowych" lub „sędziów w bieli" (Habzda-Siwek 2006).

Badania Foucaulta (2018) pokazują, że do przeniesienia ciężaru decyzji z wyroku na diagnozę doszło na początku XIX wieku, wraz z wprowadzeniem pojęcia monomanii i patologizacją pewnego obszaru przestępczości. Dzięki wpisaniu się w ramy medycyny „rozumianej jako reakcja na jawne lub potencjalne zagrożenia nieodwracalne od ciała społecznego" (Foucault 2018: 267) psychiatria uzyskała legitymizację i prestiż. Analizując związki współczesnej psychiatrii z wymiarem sprawiedliwości, warto z kolei odwołać się do rozpoznań Pierre'a Legendre'a. W pracy Zbrodnia kaprala Lortiego (2011) opisuje on, jak na salę sądową wkraczają eksperci z dziedziny psychiatrii i psychologii, którzy - stając się interpretatorami zachowań oskarżonych - mogą realnie wpływać na przebieg procesu. Biegli zyskują moc orzekania o „rozumności” oskarżonych, czyli decydowania o ich podmiotowym statusie w społeczeństwie, co Legendre uznaje za zwiastun powstania „dwugłowego wymiaru sprawiedliwości" (2011: 200).

Udział psychiatrów w głośnych procesach sądowych i rozbieżności $\mathrm{w}$ ocenie poczytalności oskarżonych dowodzą, że psychiatria może funkcjonować nie tyle jako gałąź medycyny, ile jako narzędzie kontroli społecznej. W tym kontekście warto przywołać sprawy Andersa Breivika i Karola Kota. W obu przypadkach dwa zespoły biegłych wydały sprzeczne opinie: pierwszy stwierdził ograniczoną bądź zniesioną poczytalność, a drugi uznał odpowiedzialność oskarżonych. W obu przypadkach niezwykle istotny był także czynnik presji społecznej wywieranej na psychiatrów stawiających diagnozę. Po upublicznieniu pierwszych ekspertyz doszło do silnego nacisku ze strony mediów i opinii publicznej, oczekujących, że sprawcy zostaną ukarani i „nie schronią się" w diagnozie psychiatrycznej. Sprawy te pokazuja, jak silna jest pokusa zaprzęgnięcia psychiatrii do systemu kontroli społecznej (Szafrański 2014).

Czwarte wyzwanie wynika z odmienności psychiatrii i prawa jako dyscyplin. Oczekiwania ze strony wymiaru sprawiedliwości trudno jest pogodzić z możliwościami diagnostycznymi współczesnej psychiatrii. Decyzje sądu są wiążące i mają natychmiastowy skutek, natomiast dowody psychiatryczne dotyczą spraw wielowymiarowych, które zmieniają się w czasie (Candilis i in. 2007; zob. też O’Grady 2004). Dla społeczności prawnej ,jasna i jednoznaczna definicja stanowi punkt wyjścia wszystkich podejmowanych czynności" (Gierowski 
2003: 18). Tymczasem w psychiatrii nie ma zjawisk ewidentnych (Roth, Dager 2014), a do postawienia prawidłowej diagnozy konieczne jest opracowanie specyficznej aparatury pojęciowej, odwołującej się jednocześnie do wiedzy medycznej, psychologicznej, socjologicznej czy pedagogicznej. W procesie tym tworzenie precyzyjnych definicji nie jest zadaniem podstawowym (Gierowski 2014).

Wykorzystanie współczesnej wiedzy medyczno-psychologicznej dla potrzeb wymiaru sprawiedliwości utrudnia również dogmatyczny i konserwatywny charakter prawa (Samuels, O’Driscoll, Allnutt 2007). Dyskurs prawny cechuje dążenie do unikania dwuznaczności oraz dominacja wyrażeń i struktur, które mają ustalony sposób interpretacji (Sinclair 1991), natomiast przedmiot oraz zakres psychiatrii sądowej podlegają dynamicznym zmianom. Rodzi to pytanie o możliwość odnoszenia statycznych terminów i definicji prawnych do stale rozwijającej się wiedzy psychiatrycznej (Gierowski 2006). Najczęściej przywoływanym przykładem zderzenia tych dwóch systemów kategoryzacji jest pojęcie niepoczytalności, kluczowe dla ustalenia odpowiedzialności karnej. Niepoczytalność to termin o charakterze prawnym - nie jest ani stanem psychopatologicznym, ani rozpoznaniem medycznym (Sinnott-Armstrong, Levy 2011; Pardo, Patterson 2013; Meynen 2016). W polskim środowisku psychiatrów sądowych od lat trwają dyskusje, czy definicja zawarta w art. 31 kodeksu karnego ${ }^{1}$ (dalej: k.k.) jest adekwatna do obecnego stanu wiedzy medycznej, a więc, czy ujęcie prawne jest kompa-

\footnotetext{
1 „Nie popełnia przestępstwa, kto z powodu choroby psychicznej, upośledzenia umysłowego lub innego zakłócenia czynności psychicznych, nie mógł w czasie czynu rozpoznać jego znaczenia lub pokierować swoim postępowaniem. Jeżeli w czasie popełnienia przestępstwa zdolność rozpoznania znaczenia czynu lub kierowania postępowaniem była w znacznym stopniu ograniczona, sąd może zastosować nadzwyczajne złagodzenie kary" (Dz. U. 1997 Nr 88 poz. 553).
}

tybilne z ujęciem psychiatrycznym (zob. Hajdukiewicz 2016). Użyte w kodeksie określenie „choroba psychiczna" jest we współczesnej psychiatrii uznawane za anachroniczne (w podręcznikach medycznych zastępuje je termin ,zaburzenie psychiczne”) i obarczone negatywnymi konotacjami (Pużyński $2007)^{2}$.

Wskazane wyżej napięcia ujmować można w szerszym kontekście, odnosząc się do rozpoznań Urlicha Becka i Christopha Laua (2005) dotyczących przemian nowoczesności. Za podstawę struktury instytucjonalnej „wczesnej” nowoczesności uznali oni logikę jednoznaczności, działającą zgodnie z zasadą „albo/albo". Na jej gruncie możliwe było wyznaczenie ścisłych granic między poszczególnymi kategoriami osób, rzeczy i działań, a w konsekwencji uznanie za nieprawomocne i odrzucenie wszystkiego tego, co nie znajdowało akceptacji w podstawowych instytucjach społeczeństwa. W warunkach „późnej” nowoczesności na plan pierwszy wysuwa się logika „zarówno/jak i”. Granice między kategoriami ulegają zatarciu, a formy działań wcześniej uznawane za przeciwstawne stały się równorzędne.

Adaptując te ustalenia do celów proponowanej analizy, można stwierdzić, że system prawa jest zakorzeniony w logice „wczesnej” nowoczesności. Organy procesowe dążą do jednoznacznych rozstrzygnięć - oskarżony może być winny albo niewinny, poczytalny albo niepoczytalny - i tego samego oczekują od biegłych. Współczesnej psychiatrii bliższa jest jednak logika „zarówno/jak i”. Zgodnie z obecnym stanem wiedzy zaburzenie psychiczne jest „zjawiskiem dynamicznym, o różnym natężeniu i nasileniu objawów (...) i zależnym od takich

\footnotetext{
${ }^{2}$ Warto zauważyć, że definicja niepoczytalności w polskim prawie karnym od ponad 85 lat funkcjonuje w niemal niezmienionym kształcie (zob. Habzda-Siwek 2006; Paprzycki 2011).
} 
elementów, jak na przykład przyjmowane leki lub czynniki zewnętrzne" (Bolechała 2009: 312). Obok strategii definiowania zaburzeń psychicznych w kategoriach "statusu”, polegającej na przypisywaniu pacjentom etykiet zaczerpniętych z podręczników diagnostycznych, rozwija się podejście „funkcjonalne", w którym ocenie podlega zdolność pacjentów do sprostania określonym wymogom (Szmukler 2014). Oznacza to, że osoba cierpiąca na przykład na schizofrenię może funkcjonować prawidłowo, a wystąpienie objawów psychotycznych nie musi się przekładać na niezdolność rozpoznania znaczenia czynu zabronionego. Zaburzenia psychiczne są, zdaniem psychiatrów, stopniowalne i należałoby je opisywać raczej w kategoriach prawdopodobieństwa czy stopnia natężenia objawów niż w kategoriach pewnej diagnozy (Bolechała 2009). Ekspertyzy bazujące na tego rodzaju rozróżnieniach nie spełniają jednak wymagań stawianych przez organy procesowe - biegli muszą jednoznacznie stwierdzać poczytalność lub jej brak.

Wiedza psychiatryczna, bazująca na logice „zarówno/jak i", nie zawsze umożliwia udzielenie kategorycznych odpowiedzi na pytania społeczności prawnej (Roth, Dager 2014). Psychiatrzy zaczynają zdawać sobie sprawę z tych ograniczeń (Tietze 2014). Coraz więcej zwolenników zyskuje pogląd, zgodnie z którym diagnostyka psychiatryczna jest w swej istocie „konstruktem społecznym, powstającym procesualnie, mocą społecznych uzgodnień, a nie jakby tego oczekiwali specjaliści od biologii i fizyki - mocą odkryć naukowych" (de Barbaro 2014: 15). Jeśli przyjąć, że rolą psychiatrii jest wyznaczanie granicy, poza którą leży przestępczość lub szaleństwo, to wy wiązanie się z niej nastręcza coraz więcej problemów. Kluczowa dychotomia normalne versus patologiczne staje się coraz mniej ostra, a racjonalizacja granic - coraz trudniejsza.

\section{Metoda i dane}

Do analizy włączyłam opinie wydawane w sprawach karnych, w których biegli musieli dokonać oceny poczytalności oskarżonego lub podejrzanej w chwili popełniania czynu zabronionego. Ocena poczytalności jest jednym z najczęstszych zadań psychiatrów sądowych, które nie może zostać wykonane przez biegłych reprezentujących inne specjalności (Krakowiak 2018), a zarazem „dominującym, a niejednokrotnie jedynym przedmiotem zainteresowania organów procesowych problematyką psychiatryczną i psychologiczną w procesie karnym" (Paprzycki 2011: 103).

Utworzony przeze mnie korpus składa się z 65 opinii sądowo-psychiatrycznych z lat 2015-2018 wydanych przez 8 biegłych psychiatrów pracujących w dwuosobowych zespołach ${ }^{3}$, a w jednym przypadku w zespole trzyosobowym, o zróżnicowanych składach (łącznie 20 różnych zespołów), reprezentujących referencyjny ośrodek orzecznictwa psychiatrycznego. Wybór wynikał z dwóch czynników. Po pierwsze, wybrany ośrodek wyznacza standardy opiniowania, przejmowane następnie przez inne jednostki (jego pracownicy opracowali szereg publikacji dotyczących sporządzania ekspertyz). Opinie włączone do analizy powinny być więc możliwie dobrze uzasadnione i skonstruowane, co nie jest regułą w przypadku opiniowania w Polsce (zob. Pyrcak 2010; Kacperska i in. 2016). Po drugie, wybrany ośrodek ma status referencyjnego, a jego pracownicy wydają ekspertyzy na zlecenie sądów i prokuratur z całego kraju. Zakres opiniowanych spraw jest zatem bardzo szeroki i obejmuje przypadki szczególnie trudne i kontrowersyjne.

\footnotetext{
3 Zgodnie $\mathrm{z}$ zapisami kodeksu postępowania karnego (Dz. U. 1997 Nr 89 poz. 555) w celu wydania opinii o stanie zdrowia psychicznego oskarżonego powołuje się dwóch biegłych lekarzy psychiatrów (Habzda-Siwek 2006).
} 
Do korpusu nie włączyłam opinii uzupełniających, w których organy procesowe oczekiwały od biegłych odpowiedzi na pytania szczegółowe, ani opinii dotyczacych tych samych osób i opracowanych przez tych samych psychiatrów na zlecenie innych sądów lub prokuratur. Ekspertyzy miały charakter niejawny i zostały udostępnione wyłącznie w celach naukowych, przy zachowaniu zasad ochrony danych osobowych i bez możliwości dalszego przekazywania innym osobom lub podmiotom. Materiał został poddany anonimizacji. Przeprowadziłam także korektę językową, usuwając błędy, które mogłyby utrudnić proces analizy morfosyntaktycznej, niezbędnej do zastosowania narzędzi lingwistyki korpusowej. Tak opracowany korpus liczył 557670 tokenów (507 496 słów) $)^{4}$. Należy zaznaczyć, że chociaż wielkość korpusu jest odpowiednia z punktu widzenia zastosowanych metod analizy (zob. Pawlikowska 2012), fakt, że teksty pochodzą z jednego ośrodka i były opracowane przez stosunkowo niewielką grupę psychiatrów, może negatywnie wpływać na wiarygodność wyników i utrudniać formułowanie ogólnych wniosków.

Wstępna analiza materiału wykazała, że opinie sądowo-psychiatryczne mają charakter bardzo niejednorodny. W ich początkowej części biegli przedstawiali obszerny wyciacg z akt sprawy oraz dokumentacji medycznej. Przytaczali treść dokumentów w dosłownym brzmieniu i nie podejmowali próby ich uporządkowania czy stworzenia wokół przywoływanych tekstów własnej narracji. W kolejnych segmentach opinii, które można określić jako „,autorskie”, psychiatrzy opisywali przebieg

\footnotetext{
$\overline{{ }^{4} \text { Token (segment) }}$ to podstawowy element tekstu, który zdefiniować można jako ciąg znaków interpretowany pod względem fleksyjnym, niezawierający odstępów i zwykle niezawierający znaków interpunkcyjnych. W tym ujęciu token jest w większości przypadków tożsamy ze słowem tekstowym. Istnieją jednak odstępstwa od tej reguły (zob. Woliński 2019).
}

przeprowadzonego przez siebie badania, omawiali całość materiału i budowali argumentację, kończąc na postawieniu wniosków i sformułowaniu odpowiedzi na pytania organów procesowych. Z tego względu zdecydowałam się utworzyć podkorpus (dalej: podkorpus OSP), który liczył 256722 tokenów i zawierał wyłącznie "autorskie" - napisane przez opiniujących w ich własnym języku - fragmenty ekspertyz. Wyłączyłam zatem wyciąg z akt sprawy i opis dokumentacji medycznej.

W celu przeanalizowania specyfiki języka psychiatrii sądowej na tle języka prawa i języka medycyny utworzyłam dwa dodatkowe korpusy: korpus tekstów prawnych oraz korpus psychiatrii klinicznej. Pierwszy liczył 199250 tokenów i obejmował najważniejsze zbiory przepisów prawa karnego, a więc kodeks karny (Dz. U. 1997 Nr 88 poz. 553), kodeks postępowania karnego (Dz. U. 1997 Nr 89 poz. 555) i kodeks karny wykonawczy (Dz. U. 1997 Nr 90 poz. 557). Drugi liczył natomiast 338998 tokenów i składał się z treści podstawowego podręcznika psychiatrii dla studentów medycyny, rekomendowanego przez Zarząd Główny Polskiego Towarzystwa Psychiatrycznego (Bilikiewicz 2006).

W badaniu zastosowałam podejście określane jako mixed methods research (Creswell 2003; Tashakkori, Teddlie 2003). Rozpoczęłam od analiz ilościowych z wykorzystaniem metod językoznawstwa korpusowego (zob. Kennedy 1998; Sinclair 2003; 2004). Badania korpusowe umożliwiają uchwycenie wzorców leksykalno-gramatycznych i wskazanie „nieoczywistych tendencji obecnych $\mathrm{w}$ analizowanym materiale", trudnych do wykrycia w badaniach jakościowych (Kamasa 2014: 111). Wspierają tym samym proces analizy porównawczej różnych dyskursów. Uzyskane wzorce poddałam analizie o charakterze jakościowym, skupiając się na funkcjach, jakie peł- 
nią w tekście określone słowa czy grupy słów, i proponując pogłębioną, kontekstualną interpretację danych ilościowych.

Pierwszym etapem analizy było utworzenie list frekwencyjnych (ang. word list lub frequency list), czyli list słów pojawiających się $\mathrm{w}$ korpusach - w tym przypadku w korpusie głównym i podkorpusie OSP - wraz z częstotliwością ich występowania (Baker 2006). Pozwoliło to na rekonstrukcję słownika psychiatrii sądowej (tzw. leksyki częstej). Szczegółowej analizie poddałam 20 słów o najwyższej frekwencji z wyłączeniem wyrazów, które nie były nośnikami znaczeń i pełniły jedynie funkcje gramatyczne (np. w, nie, się). Dla otrzymanych leksemów (wyrazów słownikowych) wygenerowałam konkordancje, a więc listy wystąpień wraz z najbliższym kontekstem - słowami pojawiającymi się przed i po danym pojęciu (Baker 2006). Analiza konkordancji umożliwiła mi wskazanie wzorców użycia wyróżnionych leksemów oraz otaczających je dyskursów.

Następnie przeprowadziłam analizę słów kluczowych dla podkorpusu OSP, wykorzystując metodę korpusów porównawczych. Do obliczania kluczowości zastosowałam test log-likelihood. Korpusami referencyjnymi były korpus tekstów prawnych oraz korpus psychiatrii klinicznej. Na podstawie analizy konkordancji 50 słów o najwyższej kluczowości - występujących statystycznie znacząco częściej w podkorpusie OSP niż w korpusach referencyjnych - podzieliłam na grupy tematyczne.

Ostatnim etapem była rekonstrukcja stylu narracyjnego ekspertyz. W tym celu z poziomu leksykalnego przeszłam na poziom struktur gramatycznych. Przeprowadziłam analizę czasowników jako części mowy szczególnie istotnej z punktu widzenia konstruowania narracji, a także analizę zaimków oso- bowych i dzierżawczych, których użycie uznawane jest za jeden z podstawowych wyznaczników stylu (Pennebaker 2011).

Większość analiz wykonałam w programie \#LancsBox v. 4.x (Brezina, McEnery, Wattam 2015; Brezina, Timperley, McEnery 2018). Ze względu na silnie fleksyjny charakter języka polskiego korpusy poddałam lematyzacji, która polega na sprowadzeniu każdej formy wyrazowej do jej formy podstawowej (słownikowej). W tym celu wykorzystałam aplikację LEM (Piasecki, Walkowiak, Maryl b.d.). Analizę czasowników i zaimków wykonałam natomiast w programie Verbs (Walkowiak 2017).

\section{Słownik psychiatrii sądowej}

Listy frekwencyjne, utworzone dla korpusu głównego oraz dla podkorpusu OSP, umożliwiły identyfikację podstawowego zasobu słów wykorzystywanego $\mathrm{w}$ opiniowaniu sądowo-psychiatrycznym (tab. 1). Było ono zróżnicowane. Na listach znalazły się leksemy o charakterze medycznym, związane z procesem diagnozy i leczenia („badanie”, „zaburzenie”, „objaw”, „lek”), ale dominowały pojęcia odnoszące się do zadań stawianych biegłym przez organy procesowe oraz terminy, które przynajmniej pozornie nie należą ani do słownika psychiatrii, ani do słownika prawa.

Wysoka frekwencja leksemów „dzien'” i „okres” wynika z kontekstu instytucjonalnego. Każdy z dokumentów przywoływanych w sprawozdaniu $z$ akt sprawy był opatrzony datą dzienną, datowane były także badania sądowo-psychiatryczne. Z kolei w autorskich segmentach ekspertyz biegli przeprowadzali analize "linii życiowej” i rekonstruowali rozwój zaburzeń psychicznych opiniowanego, począwszy od "okresu wczesnodziecięcego" przez 
„okres przedszkolny” i „młodzieńczy” aż po „okres poprzedzający czyn".

Termin „opiniować" używany był zazwyczaj w formie imiesłowu „opiniowany” do określenia osoby, której dotyczyła dana opinia. Łącznie zidentyfikowałam 1678 takich użyć (96,5\% wystąpień lematu), w tym 1262 w rodzaju męskim i 416 w rodzaju żeńskim. Był to podstawowy sposób określania osoby opiniowanej, a zarazem słowo swoiste dla ekspertyz sądowych jako gatunku. W analizowanych dokumentach analogiczną funkcję pełniły leksemy „oskarżony” (442 wystąpień), „podejrzany” (476), „pacjent” (558) oraz „badany” (535). Dwa pierwsze, charakterystyczne dla języka prawa, pojawiały się najczęściej w początkowych partiach opinii $\mathrm{w}$ związku z przywoływaniem wybranych fragmentów akt sprawy i pytań sformułowanych przez organ procesowy. Można przypuszczać, że nie były określeniami preferowanymi przez biegłych - jeśli psychiatrzy nie odnosili się bezpośrednio do dokumentów procesowych, wybierali zazwyczaj terminy „badany” i „opiniowany”. Należy odnotować, że biegli posługiwali się również imieniem i nazwiskiem osoby opiniowanej, przy czym czynili to z reguły albo w końcowych partiach tekstu (omówienie i wnioski), albo w jego partiach początkowych (opis sprawy i przytoczenie pytań organu procesowego). W pozostałych segmentach dominowały opisane wyżej formy, które Resnick i Soliman (2011) uznali za dehumanizujące.

Określenie „pacjent” występowało przede wszystkim w cytatach z dokumentacji medycznej. Biegli unikali stosowania go $\mathrm{w}$ autorskich segmentach opinii, zaznaczając swój dystans wobec oskarżonego. Nie byli jednak konsekwentni. W podkorpusie OSP leksem „pacjent” (w liczbie pojedynczej) pojawił się 143 razy. Część z tych wystąpień wynikała z ponownego przywołania - zazwyczaj w formie parafrazy - obserwacji i rozpoznań zawartych $\mathrm{w}$ dokumentacji medycznej $\mathrm{w}$ celu wzmocnienia argumentacji (np. „Stwierdzono, że pacjent ujawnia urojeniowy model myślenia”, „W trakcie hospitalizacji pacjent pozostawał w wyrównanym nastroju i napędzie"). Część związana była z wyjaśnieniem przyjętych $\mathrm{w}$ psychiatrii kryteriów diagnostycznych i nie odnosiła się bezpośrednio do osoby opiniowanej (np. „Różnicowanie między manią i hipomanią oparte jest $\mathrm{w}$ znacznej mierze na kryterium funkcjonowania pacjenta"). Część jednak pojawiła się w opisach obserwacji biegłych dotyczących zachowania opiniowanych oraz okoliczności badania sądowo-psychiatrycznego, zwłaszcza jeśli wiązało się z pobytem na oddziale psychiatrycznym (np. „Pacjent zgłosił się na badanie o czasie, został przyprowadzony do Kliniki przez mamę" ${ }^{\prime 5}$, „Pacjent nie odpowiadał zgodnie z prawdą na pytania odnośnie fazy uzależnień związane z zażywaniem alkoholu"). Brak konsekwencji w określaniu osoby będącej przedmiotem opinii wskazuje, że psychiatrom trudno jest zrezygnować ze słownictwa wykorzystywanego w codziennej praktyce lekarskiej i zastąpić relację lekarz-pacjent relacją ekspert-opiniowany. Należy zaznaczyć, że leksem "pacjent” wystąpił w 32 ekspertyzach, w tym w jednej aż 29 razy, a w kolejnych 8 powyżej 5 razy. Analiza dystrybucji słowa „pacjent” w dokumentach opracowanych przez poszczególne zespoły biegłych nie wykazała wyraźnego związku pomiędzy tendencją do używania tego określenia a autorstwem opinii. Ponieważ jednak $w$ analizie uwzględnione zostały

\footnotetext{
5 W tym przypadku zastanawiać może również użycie w dokumencie urzędowym wyrazu potocznego "mama”. Należy zaznaczyć, że opiniowany nie był dzieckiem $\mathrm{w}$ momencie badania miał 38 lat. $\mathrm{W}$ podkorpusie OSP leksem „mama” wystąpił aż 287 razy, ale z reguły pojawiał się $\mathrm{w}$ cytatach $\mathrm{z}$ wywiadu zebranego od opiniowanego. Przywołane użycie można tłumaczyć przejmowaniem przez biegłych języka opiniowanych.
} 
wyłącznie opinie z jednego ośrodka, opracowane przez stosunkowo niewielką grupę psychiatrów, nie można wykluczyć, że tendencja ta ma charakter lokalny.

Leksem „opinia” odnosił się zazwyczaj do opinii innych biegłych. W zdecydowanej większości przypadków (50 opinii) autorzy analizowanych tekstów nie byli pierwszym zespołem psychiatrów powołanym $\mathrm{w}$ danej sprawie. Za każdym razem odwoływali się do wcześniejszych ekspertyz, cytując fragmenty ustaleń poprzedników. Termin „opinia” - stosowany wymiennie z określeniami „podsumowanie” i „wnioski” - funkcjonował również jako tytuł końcowej części analizowanych dokumentów.

Leksem „psychiczny” wykorzystywany był najczęściej jako kolokat leksemów „stan” (491 wystąpień), "choroba” (313), „zdrowie” (160) i „zaburzenie” (92). Stanowił także człon kolokacji trójwyrazowych "stan zdrowia psychicznego" (88), „ocena stanu psychicznego" (49), „objaw choroby psychicznej” (42), "aktualny stan psychiczny” (26), „obecny stan psychiczny” (13), a także czterowyrazowej „inne zakłócenie czynności psychicznych" (65). Część wskazanych kolokacji wywodzi się z języka psychiatrii klinicznej, część z leksyki prawnej. „Stan zdrowia” $\mathrm{i}$ „,stan psychiczny” należą do obu tych grup - występowały zarówno w korpusie psychiatrii klinicznej, jak i korpusie tekstów prawnych ${ }^{6}$.

Biegli bardzo rzadko posługiwali się terminami „niepoczytalność” i „niepoczytalny” (w korpusie

\footnotetext{
${ }^{6}$ Zgodnie $\mathrm{z}$ art. 202 § 5 kodeksu postępowania karnego w opinii biegli powinni odnieść się nie tylko do kwestii poczytalności oskarżonego lub podejrzanej w chwili popełnienia czynu, lecz także dokonać oceny ich aktualnego „stanu zdrowia psychicznego" (pojęcie to nie zostało zdefiniowane przez ustawodawcę) oraz zdolności do udziału w postępowaniu sądowym, a w razie potrzeby ocenić ryzyko ponowienia czynu zabronionego i zalecić bądź nie zastosowanie środka zabezpieczającego.
}

głównym pojawiły się one odpowiednio 25 i 7, zaś w podkorpusie OSP - 11 i 3 razy), a niepoczytalność określali za pomocą wyrażeń zaczerpniętych $\mathrm{z}$ art. 31 k.k. Jednym z nich była "choroba psychiczna”. Chociaż frekwencja leksemu „zaburzenie" była wyższa niż frekwencja leksemu „,choroba”, termin „choroba psychiczna”, uznawany w psychiatrii klinicznej za anachroniczny, pojawiał się w korpusie częściej niż „zaburzenie psychiczne”. Leksem „zaburzenie” stosowany był zwykle do stawiania konkretnych rozpoznań medycznych (np. zaburzenia nastroju czy zaburzenia afektywno-dwubiegunowe). $\mathrm{O}$,"chorobie psychicznej" biegli pisali przede wszystkim w omówieniu wyników i w końcowych wnioskach, a więc $w$ segmentach opinii o kluczowym znaczeniu z punktu widzenia czynności procesowych. Często wykorzystywali także inne wyrażenia występujące w art. 31 k.k.: „rozpoznanie znaczenia” (131 wystąpień), „pokierować swoim postępowaniem” (211) oraz „upośledzenie umysłowe” (188).

Można się zastanawiać, na ile wskazane tendencje wynikają z chęci przełożenia ustaleń medycznych na język prawa, na ile zaś z przyswojenia pojęć zaczerpniętych z kodeksu karnego i uczynienia ich elementem języka zawodowego. W tym kontekście warto zwrócić uwagę na wyrażenie „inne zakłócenie czynności psychicznych". Biegli traktowali je niekiedy jako rozpoznanie i doprecyzowywali $\mathrm{w}$ terminach właściwych psychiatrii klinicznej („U podejrzanego rozpoznajemy inne zakłócenia czynności psychicznych o obrazie przewlekłej halucynozy z epizodami majaczeniowymi”, „[Opiniowany] w chwili popełnienia zarzucanego mu czynu cierpiał na inne zakłócenia czynności psychicznych pod postacią zaburzenia osobowości"). Ten sposób użycia pokazuje, że włączając do swojego repertuaru terminy prawne, psychiatrzy podejmują próbę „obudowania" ich własnym aparatem pojęciowym. 
Stanowi także reakcję na brak precyzji prawodawcy, który nie określił, jak należy rozumieć poszczególne składowe kodeksowej definicji niepoczytalności, pozostawiając biegłym duży margines swobody.

Leksem „czyn”, nieobecny w korpusie psychiatrii klinicznej w kontekście innym niż sądowy, jest jednym z najlepiej przyswojonych przez biegłych terminów wywodzących się z prawa karnego. Autorzy opinii bardzo często wprowadzali słownictwo prawne $\mathrm{w}$ formie sekwencji wielowyrazowych przejętych wprost z kodeksu karnego, jednak leksem „czyn” stosowany był bez dodatkowych dookreśleń7. Warto zauważyć, że słowa „czyn” i „zachowanie”, choć częściowo synonimiczne, miały $\mathrm{w}$ analizowanych tekstach odmienne znaczenia. Pierwsze posiadało wąskie znaczenie prawne i wydźwięk negatywny, natomiast drugie miało szerszy zakres znaczeniowy i nie było nacechowane ani pozytywnie, ani negatywnie. Zazwyczaj nie były one stosowane wymiennie. Pojawiały się jednak wyjątki od tej reguły (,ZZdaniem biegłych ryzyko recydywy zachowań takich samych, o które podejrzany jest (...), bądź podobnych, jest bardzo niskie"), co może świadczyć o trudnościach z uzgodnieniem języka prawnego i pozaprawnego.

Kolejnymi leksemami wywodzącymi się z języka prawa są „biegły” i „sprawa”. Pierwsze traktowane było przez autorów opinii jako podstawowe określenie pełnionej przez nich funkcji, natomiast drugie jako podstawowe określenie procesu sądowego. Co istotne, jako o „psychiatrach” (a właściwie „specjalistach psychiatrach" lub „lekarzach psychiatrach") biegli pisali o sobie jedynie na początku opinii, podając dane osobowe.

${ }^{7}$ Wyjątek stanowił termin "czyn zabroniony" (82 wystąpienia), ale był on wykorzystywany wyłącznie w końcowych częściach opinii, w kontekście oceny ryzyka ponownego popełnienia przestępstwa.
Wysoką frekwencję leksemu "alkohol” tłumaczyć można faktem, że pytanie o spożycie, a w szczególności „nadużywanie alkoholu” (119 wystąpień) i „uzależnienie od alkoholu” (124) zarówno przez osobę opiniowaną, jak i członków jej rodziny, było jednym z podstawowych pytań zadawanych przez psychiatrów w trakcie wywiadu. W podobny sposób wyjaśnić można obecność na listach frekwencyjnych leksemów „dom”, „dziecko”, „ojciec” i „żona” - sytuacja rodzinna opiniowanych omawiana była szeroko w ramach analizy ich „linii życiowej”.

Chociaż mogłoby się wydawać, że leksyka opinii ujmowanych jako całość, a więc zawierających obszerne sprawozdania $\mathrm{z}$ analizy akt, powinna się różnić od słownictwa stosowanego w ",autorskich" segmentach opinii, listy 20 najczęstszych słów korpusu głównego i podkorpusu OSP są do siebie bardzo podobne $\mathrm{i}$ - poza pojedynczymi wyjątkami - obejmują te same leksemy, w niemal identycznej kolejności. Analiza słów znajdujących się na dalszych pozycjach pozwoliła jednak uchwycić istotne różnice. W podkorpusie OSP stosunkowo często występowały formuły charakterystyczne dla gatunków medycznych, w tym zwłaszcza epikryz (Górnicz 2011), które były wykorzystywane przez psychiatrów do opisu wywiadu lekarskiego - opiniowany „podawał” (385 wystąpień) i „,negował” (266) określone stany rzeczy (myśli i próby samobójcze, przyjmowanie substancji psychoaktywnych, wystąpienie objawów, samookaleczenia, urazy, choroby somatyczne, hospitalizacje), a także „odpowiadał” (230) na pytania (237) zadawane przez biegłych (zarówno pytania, jak i odpowiedzi były często cytowane). Drugą grupą słów swoistych dla podkorpusu OSP była leksyka związana z edukacją i pracą zawodową (m.in. „nauka”, ,studia”, „szkoła”, „pracować”). Wątki te - istotne z punktu widzenia rozwoju zaburzeń psychicznych, ale niekoniecznie z perspektywy przebiegu czynu - były rozpatrywa- 
ne przez biegłych w opisie badania oraz omówieniu materiału, nie pojawiały się natomiast $\mathrm{w}$ przytaczanych aktach sprawy. Z kolei w korpusie głównym znacznie częściej niż w podkorpusie OSP występowało słownictwo prawne, związane z czynnościami organów ścigania lub organów procesowych (m.in. „,świadek”, „protokół”, „przesłuchanie”, „zeznawać”, „zeznać”, „kk [kodeks karny]”) oraz z dokumentami zebranymi w trakcie dochodzenia (m.in. „protokół”, „,tom” [akt], „karta” [akt], „nieczytelny” [wpis]), a także słownictwo odnoszące się do okoliczności popełnienia czynu zabronionego (m.in. „nóż”, „bar”, „lokal”, „,kwota”, „złoty”, „rana”).

\section{Między prawem i medycyną}

W celu bardziej precyzyjnej identyfikacji leksyki swoistej dla psychiatrii sądowej oraz procesów uzgadniania języka prawa z językiem medycyny porównałam podkorpus OSP z korpusem prawnym oraz korpusem psychiatrii klinicznej, wykorzystując analizę słów kluczowych. Okazało się, że w porównaniu do zbioru tekstów prawnych w podkorpusie OSP istotnie częściej występowały nie tylko słowa odnoszące się do diagnozy medycznej (m.in. ,psychiczny”, ,objaw”, „nastrój”), ale także do czynności podejmowanych przez biegłych („badać", „badanie”, „pytać”), przebiegu życia opiniowanych, w tym zwłaszcza sytuacji rodzinnej (m.in. „żona”, „dom”, „mama”, „problem” [z nauką), historii choroby, („lek”, „choroba”, „szpital”, „problem” [zdrowotny]), wywiadu zebranego od oskarżonego (m.in. „pamiętać”, „podawać”, „negować") oraz przyjmowania substancji psychoaktywnych (,alkohol”, ,pić", „problem” [z narkotykami lub alkoholem]). Na liście słów kluczowych (tab. 2) znalazły się ponadto: leksem związany z określeniem czasu („zacząć”), który odnosił się zarówno do kolejnych etapów życia (praca, nauka, studia), jak i historii choroby oskarżonego lub podejrzanej, lek- semy związane z wydawaniem ekspertyz, określające osoby opiniowane („,opiniować” [opiniowany lub opiniowana] i "badany") oraz instytucje wydające ekspertyzy i same opinie (,,sądowy” i „psychiatria”). Słowa należące do ostatniej grupy współwystępowały zwykle ze sobą oraz z określeniami ,instytut”, „,klinika”, „oddział”, „badanie” i „opinia”. Termin „sądowy" używany był także jako kolokat leksemów „rozprawa”, „postępowanie”, „biegły” i „sprawa”. Teksty włączone do podkorpusu OSP cechowały się ponadto wyższą niż w korpusie prawnym frekwencją niektórych zaimków (,ja”, „swój”, „to", ,jak"), przyimków (,'u”, „po"), spójników (,że”, ,"ale”, „,bo”, „ż̇eby”) oraz partykuł („,nie", „czy").

Na podobne grupy tematyczne podzielić można słowa kluczowe wyróżnione na podstawie porównania z korpusem psychiatrii klinicznej (tab. 3). W podkorpusie OSP istotnie częściej pojawiała się leksyka odnosząca się do przebiegu życia opiniowanych, w tym także ich sytuacji zawodowej i mieszkaniowej (m.in. „żona”, „dom”, „pracować”, „mieszkać”), zebranego wywiadu (m.in. „,negować”, ,pamiętać", ,twierdzić”), wydawania opinii („opiniować", „badany”, „opinia”) oraz słowa pełniące funkcje gramatyczne: zaimki (,ja”, „swój”, „on”, „to”, „nic”), przyimki (,w”, „z", „po”), spójniki (,ż̇e”, „bo”, „żeby”, „ale”) i partykuły (,nie", „,czy”). Mniej liczne niż w przypadku poprzedniego zbioru słów kluczowych były grupy leksemów określających czynności podejmowane przez biegłych („pytać”) i spożycie alkoholu („alkohol”). Zgodnie z oczekiwaniami nieobecne było słownictwo związane $\mathrm{z}$ diagnostyką i historią choroby. Znacznie liczniejsza okazała się natomiast grupa wyrażeń określających czas (m.in. „rok”, „dzien'”, „nigdy”). Warto zaznaczyć, że tendencja do ich używania jest uznawana za jeden z podstawowych wyróżników języka prawa (Zozula 2019). Na liście słów kluczowych pojawiła się także leksyka odnosząca się do czynu 
zabronionego i postępowania sądowego, ale nie była ona tak liczna, jak można by się spodziewać („,czyn", „sprawa”, „podejrzany”, ,,akta”, ,policja”).

W obu zbiorach słów kluczowych zastanawia obecność tak licznej grupy słów zaimków, przyimków i spójników. Ich nadreprezentacja sugeruje częstsze niż w tekstach prawnych i podręcznikach medycznych używanie zdań złożonych, większą subiektywizację i swobodę językową. Należy jednak zauważyć, że różnice te mogą wynikać z odmienności gatunkowych analizowanych tekstów. Wykorzystanie spójnika przeciwstawnego "ale” można z kolei wiązać z unikaniem stawiania jednoznacznych rozpoznań zgodnych z logiką „albo/albo”, właściwą dla systemu prawnego. Co ciekawe, im bliżej końcowych wniosków, tym logika ta zaczynała dominować nad logiką „zarówno/jak i”. Spójnik „ale” pojawiał się zwykle w opisie wywiadu zebranego od opiniowanego i wyników badania psychiatrycznego. $W$ tych segmentach ekspertyz biegli starali się nakreślić możliwie pełny obraz funkcjonowania opiniowanego, który często trudno było wtłoczyć w ramy konkretnej jednostki chorobowej (np. „Przejawia skłonność do kumulowania i tłumienia przeżywanych emocji, ale jednocześnie charakteryzuje go nieumiejętność ich wyrażania”, „Prawdopodobnie podobne epizody, krótsze, o mniejszym nasileniu występowały już w poprzednich miesiącach w trakcie pracy, ale nie prowadziły do zaburzeń zachowania"). Formułując wnioski i odpowiadając na pytania organów procesowych, dostosowywali się do oczekiwań społeczności prawnej i stawiali pewne rozpoznania (np. „Poczytalność oskarżonego w czasie czynów nie budzi wątpliwości”, „Nie mamy zatem wątpliwości, że zachodzą w tym przypadku warunki art. $31 \S 3$ kk"). Niekiedy próbowali jednak uniknać kategorycznych odpowiedzi, wprowadzając elementy logiki „zarówno/jak i”:
Biegli rozpoznali chorobę psychiczną - schizofrenię paranoidalną, ale uznali, że motywy działania sprawcy nie wynikały z przesłanek psychotycznych.

W ostatnich latach jest przede wszystkim uciążliwy dla wymiaru sprawiedliwości i córki wraz z jej rodziną i przyjaciółki, ale z uwagi na to, że proces chorobowy jest cały czas aktywny, nie jesteśmy w stanie przewidzieć [czy] opór „wrogiego Mu” otoczenia będzie znosił spokojnie, kiedy silne napięcie emocjonalne spowodowane urojeniową interpretacją wydarzeń nie stanie się powodem zachowań agresywnych, czego próbki ujawniał w przeszłości.

W opiniach wydanych w roku 2018 biegli zastosowali nową strategię łączenia logiki prawa z logiką medycyny - określali, jak to ujęli, „prawdopodobieństwo wystąpienia określonego stanu mogącego mieć wpływ na zdolność pokierowania postępowaniem przez opiniowanego w czasie czynu":

Biorąc powyższe pod uwagę, należy przyjąć z prawdopodobieństwem graniczącym z pewnością, że w okresie objętym zarzutami z powodu objawów choroby afektywnej dwubiegunowej opiniowana znajdowała się w okresie patologicznego wzmożenia nastroju i napędu psychomotorycznego oraz zmniejszenia krytycyzmu, co do konsekwencji podejmowanych działań, a tym samym jej zdolność pokierowania swoim postępowaniem była zniesiona.

\section{Konstruowanie narracji}

Częstsze niż w obu korpusach referencyjnych wykorzystanie zaimków pełniących funkcję referencyjną (,ja”, „swój”) odsyła do kwestii budowania fabuły. Jeśli przyjąć za zwolennikami podejścia narracyjnego, że zadaniem biegłych jest wyrażenie głosu i historii osoby opiniowanej przy użyciu głosu wła- 
snego, w opiniach można wyróżnić co najmniej dwa punkty narracji: narrację opiniowanego i narrację opiniujących. Analiza form czasownikowych wypowiedzi oraz analiza zaimków wykazała, że bezpośredni głos odautorski jest w opiniach bardzo słabo widoczny (tab. 4). Biegli rzadko posługiwali się czasownikami oraz zaimkami w pierwszej osobie liczby mnogiej, występując jako „my” (1,9\% czasowników oraz 4,2\% zaimków; należy jednak zaznaczyć, że zaimki „my”, „nas” i „nam” tylko 13 razy zostały użyte bezpośrednio przez autorów opinii - pozostałe wystąpienia wiązały się z przytaczaniem zeznań i fragmentów protokołów policyjnych). Można wyróżnić trzy alternatywne wobec wykorzystania pierwszej osoby liczby mnogiej strategie narracyjne: (i) zastosowanie trzeciej osoby liczby mnogiej i pisanie o sobie jako o „biegłych” („Biegli zapoznali się szczegółowo z aktami sprawy", "Odnośnie tempore criminis biegli stwierdzają..."), (ii) używanie form bezosobowych i strony biernej („W dniu 30.09.2015 przeprowadzono badanie psychiatryczne opiniowanego”, „Badanie zostało przeprowadzone w Klinice..."), (iii) wprowadzanie zdań rozpoczynających się od sformułowań „w naszej ocenie” lub „naszym zdaniem” (alternatywnie „zdaniem biegłych”). Należy zauważyć, że zaimek dzierżawczy „nasz”, którego wykorzystanie uznać można za wskaźnik subiektywizacji tekstu (Zaśko-Zielińska 2013), przez autorów analizowanych opinii został użyty zaledwie 75 razy.

W analizowanych dokumentach narracja opiniowanych zdecydowanie przeważała nad narracją opiniujących. Wskazuje na to z jednej strony częste wykorzystanie pierwszej osoby liczby pojedynczej (11,5\% czasowników i 31,7\% zaimków), z drugiej zaś wyraźna dominacja czasowników i zaimków w trzeciej osobie liczby pojedynczej (odpowiednio 64,2\% i 55\%). Biegli oddawali głos opiniowanym, cytując fragmenty ich wypowiedzi, i skupiali się na opisie historii choroby, wyników badań oraz obserwacji zachowań podejrzanych. Mogłoby się wydawać, że w segmentach zawierających autorskie wypowiedzi biegłych, nie zaś cytaty $z$ akt sądowych, głos psychiatrów będzie silniej obecny. Tymczasem w podkorpusie OSP częstość czasowników i zaimków w pierwszej osobie liczby mnogiej była jeszcze niższa. Biegli w większym stopniu posługiwali się natomiast trzecią osobą liczby pojedynczej.

Warto zwrócić uwagę na dominację czasowników w czasie przeszłym $(58,2 \%$ w korpusie głównym i 56,1\% w podkorpusie OSP), wynikającą ze skupienia na czynie zabronionym. Chociaż zadaniem biegłych jest także ocena aktualnego stanu psychicznego oskarżonych, w opiniach zdecydowanie większy nacisk położony został na rekonstrukcję stanu tempore criminis. Z kolei stosunkowo rzadkie wykorzystywanie czasu przyszłego (odpowiednio 1,9\% i 1,7\%) i trybu przypuszczającego (0,7\% w obu zbiorach) może wskazywać, że ocena ryzyka ponownego popełnienia czynu zabronionego - a więc kolejne zadanie, jakie stawiają przed biegłymi organy procesowe - nie była przez psychiatrów rozpatrywana tak szeroko.

Unikanie stosowania form osobowych i zastępowanie ich konstrukcjami bezosobowymi, a także dominacja czasowników i zaimków w trzeciej osobie liczby pojedynczej wynikały prawdopodobnie $\mathrm{z}$ chęci zaznaczenia bezstronności spostrzeżeń i oddzielenia opisu wyników badań i obserwacji zachowań opiniowanych od głoszonych sądów. Cechy te zbliżają opinie do stylu określonego przez Jamesa Pennebakera (2011) jako formalny. Odwołując się do analiz prowadzonych przez Alfreda Verdego i zespół (2006), można stwierdzić, że pierwszeństwo w ekspertyzach miały głosy prawdy, empirii i nauki. Psychiatrzy ujmowali czyn zabroniony w kategoriach konkretnej, opisywalnej rzeczywistości faktów i działań. Wiązać 
to można $\mathrm{z}$ dążeniem do stworzenia i utrzymania profesjonalnego wizerunku oraz nadania wagi swoim ustaleniom ${ }^{8}$, ale także z próbą dostosowywania się do oczekiwań organów procesowych oraz z właściwym prawu dążeniem do obiektywności.

\section{Wnioski}

Zastosowanie analizy korpusowej w celu rekonstrukcji wzorców językowych opinii sądowo-psychiatrycznych umożliwiło uchwycenie napięć związanych z niejednoznaczną rolą psychiatrów w postępowaniu karnym i koniecznością uzgadniania dyskursów prawnego i medycznego. Wykazała ona, że na tle tekstów stricte psychiatrycznych opinie nie wyróżniają się dużym nagromadzeniem specjalistycznych terminów prawnych, a biegli często posługują się leksyką i strukturami językowymi właściwymi dla gatunków medycznych, między innymi epikryz. Do gatunków prawnych ekspertyzy sądowo-psychiatryczne upodabnia z kolei wykorzystanie wyrażeń określających czas, a także tendencja do ograniczania obecności głosu odautorskiego i eliminacja wypowiedzi wyrażających wprost opinie biegłych (unikanie pisania w pierwszej osobie liczby mnogiej i stosowanie form bezosobowych). Na tej podstawie można stwierdzić, że polscy psychiatrzy, w przeciwieństwie do biegłych amerykańskich (Candilis 2007), nie przyjmują do wiadomości, że opinie sądowo-psychiatryczne nie są obiektywnymi i bezosobowymi produktami ich pracy, a psychiatrzy sądowi jako autorzy dokonują określonych wyborów językowych i narracyjnych, które mają wpływ na oddziaływanie ich tekstów. Analizowane opinie przypominały raczej raporty z badań i miały formę dokumentacji przeprowadzonych czynności.

\footnotetext{
${ }^{8}$ Do podkreślenia pozycji i tym samym zaznaczenia swojej wiarygodności służyło biegłym m.in. wymienianie stopni i tytułów naukowych. Wagę ich wnioskom nadawało również odwoływanie się do autorytetów naukowych, np. poprzez dołączenie do opinii bibliografii.
}

Biegli nie nadawali im cech narracyjnych i nie starali się zbudować spójnej, przekonującej dla odbiorców z obszaru prawa i nie tylko opowieści wokół sprawcy czynu zabronionego. Należy podkreślić, że tendencja ta była widoczna również $\mathrm{w}$ autorskich częściach opinii, w których psychiatrzy sądowi mają większą dowolność $\mathrm{w}$ formułowaniu wypowiedzi.

W procesie uzgadniania języków prawa i psychiatrii w opiniowaniu sądowym zasadą nadrzędną okazuje się zrozumiałość dla odbiorcy (organów procesowych), a język prawa ma pierwszeństwo przed językiem psychiatrii klinicznej. Słownictwo prawne biegli przejmują zwykle $\mathrm{w}$ postaci skonwencjonalizowanych związków wyrazowych zaczerpniętych wprost z kodeksu karnego. Wprowadzając do ekspertyz pojęcia kodeksowe, próbują obudować je aktualną wiedzą medyczną i psychologiczną. Tak rozumiany proces translacji ułatwia brak precyzyjnej definicji niepoczytalności i związana z tym swoboda interpretacyjna. Wysoka frekwencja wyrażenia "choroba psychiczna”, obecnego w tekstach prawnych, ale wycofywanego z tekstów medycznych, pokazuje, że dostosowywanie się do oczekiwań odbiorców z obszaru prawa wiąże się niekiedy z koniecznością rezygnacji z poprawności językowej i metodologicznej, przyjętych na gruncie medycyny.

Analiza korpusowa uwidoczniła nie tylko trudności językowe, ale także wyzwania etyczne, z jakimi muszą mierzyć się psychiatrzy sądowi, wynikające z podwójnej roli - lekarza i biegłego sądowego. Autorzy analizowanych tekstów skupiali się na realizacji drugiej z tych ról, sytuując się po stronie prawa. Widać to wyraźnie w sposobie, w jaki określali osobę opiniowaną. $Z$ reguły korzystali z terminów prawnych oraz terminu naukowego „badany”, zaznaczając swój dystans wobec oskarżonego. Zastępowanie relacji lekarz-pacjent relacją ekspert-opiniowany nie zawsze 
im się jednak udawało. Obecność określenia „pacjent” może wynikać z nawyków językowych, ale może też oznaczać, że biegłym trudno jest wyjść z roli lekarza skupionego przede wszystkim na dobru jednostki, nie zaś dobru społecznym - postrzegają opiniowanego jako osobę chora, wymagającą opieki i leczenia (pacjenta), nie zaś jako podmiot racjonalny, podlegający kontroli, który może być ukarany i poddany resocjalizacji (przestępcę).

Można się zastanawiać, na ile wskazane różnice wynikają z odmienności języków prawa, medycyny i psychiatrii sądowej, na ile zaś z odmienności gatunkowych analizowanych tekstów. Opinia sądowa ma inną formę, inny status i inne funkcje niż podręcznik czy zbiór przepisów prawa, co może przekładać się na wyniki analiz. W celu weryfikacji postawionych wniosków i pełniejszego uchwycenia specyfiki języka psychiatrii sądowej warto rozważyć porównanie opinii sądowo-psychiatrycznych nie tylko z tekstami "teoretycznymi" (metatekstami), takimi jak kodeksy i komentarze do obowiązujących przepisów prawa karnego oraz podręczniki psychiatrii, ale także z tekstami „praktycznymi”, w szczególności z uzasadnieniami wyroków sądowych oraz epikryzami psychiatrycznymi. Należy również podkreślić, że analizowany korpus zawiera opinie pochodzące z jednego ośrodka, opracowane na przestrzeni 4 lat i nie jest reprezentatywny dla całego zbioru opinii sądowo-psychiatrycznych w Polsce. Wyniki badań dotyczących dyskursu specjalistycznego wskazuja, że budowa i skład korpusu mają bardzo duży wpływ na zmienność leksykalną (zob. Miller, Biber 2015). Ze względu na nowatorski charakter analiz i brak materiału porównawczego trudno oszacować wpływ idiolektu poszczególnych biegłych na uzyskane wyniki. Na potrzeby dalszych badań korpus powinien zostać rozszerzony o opinie wydawane przez różne ośrodki psychiatrii sądowej.
W opisie wyników badania i omówieniu materiału biegli pozwalali sobie na formułowanie rozpoznań niepewnych, ale bardziej zniuansowanych, uwzględniających między innymi zmienność i siłę natężenia objawów. Ten sposób opisu nie spełnia wymogów stawianych przez organy procesowe - opinia psychiatryczna musi zawierać jednoznaczne rozstrzygnięcia dotyczące zaleconych badań, a biegły powinien unikać sformułowań w rodzaju: „,wydaje mi się”, , ,można przypuszczać”, ,jeśli się nie mylę” czy „prawdopodobnie” (Wolska 1998: 102; zob. też Stanik 1980; Marton 1990). Dlatego w końcowych segmentach opinii psychiatrzy sądowi musieli porzucić zasadę „zarówno/jak i” na rzecz zasady ",albo/albo", formułując jednoznaczne odpowiedzi na pytania organów procesowych. Niekiedy próbowali pogodzić te podejścia, stopniując prawdopodobieństwo wystąpienia zaburzeń prowadzących do niepoczytalności. Z tej perspektywy $\mathrm{w}$ analizowanych tekstach dostrzec można wyraźnie zderzenie dwóch logik: logiki „albo/albo”, właściwej dla systemu sprawiedliwości, zakorzenionego we „wczesnej” nowoczesności, oraz logiki „zarówno/jak i”, przyjmowanej we współczesnej psychiatrii klinicznej.

Pęknięcie to można odczytywać jako przejaw dążenia do zachowania autonomii psychiatrii jako dyscypliny w ramach procedury postępowania sądowego. Można jednak zaproponować alternatywną interpretację, zgodnie z którą stanowiłoby ono reakcję na przypisywanie psychiatrom nadmiernej odpowiedzialności wynikającej z roli „sędziów naukowych”. W Polsce ekspertyzy biegłych mają decydujące znaczenie dla rozstrzygnięć organów procesowych (Habzda-Siwek 2006). Unikanie definitywnych konkluzji, trudnych do wypracowania na gruncie psychiatrii, a także nienarracyjny charakter opinii osłabiają ich perswazyjną wymowę i pozostawiają przestrzeń do wątpliwości. $\mathrm{W}$ efekcie zadanie interpretacji wniosków z badania psychiatrycznego wraca do sędziów. 


\section{Aneks}

Tabela 1. Lista 20 słów o najwyższej liczbie wystąpień dla korpusu głównego oraz podkorpusu OSP

\begin{tabular}{|c|c|c|c|c|c|}
\hline \multicolumn{3}{|c|}{ Korpus główny } & \multicolumn{3}{|c|}{ Podkorpus OSP } \\
\hline Lemat & Frekwencja & $\%$ & Lemat & Frekwencja & $\%$ \\
\hline dzień & 2547 & $0,5 \%$ & opiniować & 1172 & $0,5 \%$ \\
\hline opiniować & 1739 & $0,3 \%$ & psychiczny & 742 & $0,3 \%$ \\
\hline stan & 1550 & $0,3 \%$ & stan & 735 & $0,3 \%$ \\
\hline psychiczny & 1322 & $0,2 \%$ & czyn & 720 & $0,3 \%$ \\
\hline czyn & 1273 & $0,2 \%$ & dzień & 719 & $0,3 \%$ \\
\hline sprawa & 1220 & $0,2 \%$ & zaburzenie & 646 & $0,3 \%$ \\
\hline badanie & 1195 & $0,2 \%$ & badanie & 621 & $0,2 \%$ \\
\hline zaburzenie & 1152 & $0,2 \%$ & sprawa & 615 & $0,2 \%$ \\
\hline psychiatryczny & 1096 & $0,2 \%$ & okres & 580 & $0,2 \%$ \\
\hline opinia & 1011 & $0,2 \%$ & alkohol & 578 & $0,2 \%$ \\
\hline alkohol & 971 & $0,2 \%$ & dom & 506 & $0,2 \%$ \\
\hline dom & 960 & $0,2 \%$ & praca & 494 & $0,2 \%$ \\
\hline choroba & 951 & $0,2 \%$ & choroba & 493 & $0,2 \%$ \\
\hline okres & 932 & $0,2 \%$ & psychiatryczny & 481 & $0,2 \%$ \\
\hline dziecko & 932 & $0,2 \%$ & dziecko & 465 & $0,2 \%$ \\
\hline biegły & 857 & $0,2 \%$ & żona & 458 & $0,2 \%$ \\
\hline praca & 846 & $0,2 \%$ & objaw & 454 & $0,2 \%$ \\
\hline objaw & 834 & $0,1 \%$ & opinia & 434 & $0,2 \%$ \\
\hline ojciec & 823 & $0,1 \%$ & ojciec & 427 & $0,2 \%$ \\
\hline zachowanie & 775 & $0,1 \%$ & lek & 419 & $0,2 \%$ \\
\hline
\end{tabular}

Źródło: opracowanie własne.

Tabela 2. 50 słów kluczowych wyróżniających podkorpus OSP na tle korpusu prawnego, w podziale na grupy tematyczne

\begin{tabular}{ll}
\hline Kategoria & Leksemy \\
\hline diagnoza & psychiczny, zaburzenie, objaw, stan, choroba, nastrój \\
wydawanie opinii & opiniować, badany, sądowy, psychiatria \\
sytuacja rodzinna & żona, dom, ojciec, matka, mama, dziecko, mąż, problem \\
wywiad od opiniowanego & pamiętać, wiedzieć, chcieć, podawać, mówić, negować \\
czynności biegłych & badać, badanie, pytać \\
określenie czasu & zacząć \\
historia choroby & lek, choroba, szpital, problem \\
spożycie alkoholu & alkohol, pić, problem \\
słowa o funkcjach gramatycznych & ja, swój, to, jak, u, o, że, ale, bo, żeby, nie, czy \\
inne & być, mieć, chcieć, dobrze, sytuacja \\
\hline
\end{tabular}

Źródło: opracowanie własne. 
Tabela 3. 50 słów kluczowych wyróżniających podkorpus OSP na tle korpusu psychiatrii klinicznej, w podziale na grupy tematyczne

\begin{tabular}{ll}
\hline Kategoria & Leksemy \\
\hline wydawanie opinii & opiniować, badany, opinia \\
sytuacja rodzinna & żona, ojciec, dom, pracować, mama, matka, mąż, mieszkać, córka, siostra, brat \\
wywiad od opiniowanego & negować, pamiętać, wiedzieć, twierdzić, podawać \\
czyn zabroniony & czyn, sprawa, podejrzany, akta, policja \\
czynności biegłych & pytać \\
określenie czasu & rok, dzień, potem, zacząć, chwila, nigdy, kiedy \\
spożycie alkoholu & alkohol \\
słowa o funkcjach gramatycznych & nie, że, ja, swój, on, bo, to, w, żeby, czy, nic, z, ale, po \\
inne & mieć, chcieć, mieć być [miałbym/miałabym] \\
\hline
\end{tabular}

Źródło: opracowanie własne.

Tabela 4. Charakterystyka czasownikowa i zaimkowa wypowiedzi w podziale na korpus główny oraz podkorpus OSP

\begin{tabular}{lcc}
\hline \multirow{2}{*}{ Formy } & \multicolumn{2}{c}{ Częstości } \\
\cline { 2 - 3 } & Korpus główny & Podkorpus OSP \\
\hline Tokeny ogółem & 562714 & 257985 \\
Czasowniki & $64584(11,5 \%)^{*}$ & $32681(12,7 \%)^{*}$ \\
1 os. l. pojedynczej & $7813(12,1 \%)$ & $3696(11,3 \%)$ \\
1 os. l. mnogiej & $1205(1,9 \%)$ & $536(1,6 \%)$ \\
3 os. l. pojedynczej & $41473(64,2 \%)$ & $21327(65,3 \%)$ \\
3 os. 1. mnogiej & $5593(8,7 \%)$ & $2884(8,8 \%)$ \\
Bezokoliczniki & $5557(8,6 \%)$ & $2930(9,0 \%)$ \\
Czasowniki bezosobowe & $2728(4,2 \%)$ & $1251(3,8 \%)$ \\
Tryb przypuszczający & $469(0,7 \%)$ & $244(0,7 \%)$ \\
Czas teraźniejszy & $19610(30,4 \%)$ & $10603(32,4 \%)$ \\
Czas przeszły & $37588(58,2 \%)$ & $18319(56,1 \%)$ \\
Czas przyszły & $1231(1,9 \%)$ & $546(1,7 \%)$ \\
Zaimki & $11941(2,1 \%)^{*}$ & $4979(1,9 \%)^{*}$ \\
1 os. 1. pojedynczej & $3782(31,7 \%)$ & $1349(27,1 \%)$ \\
1 os. l. mnogiej & $501(4,2 \%)$ & $143(2,9 \%)$ \\
3 os. l. pojedynczej & $6573(55,0 \%)$ & $3017(60,6 \%)$ \\
3 os. l. mnogiej & $991(8,3 \%)$ & $434(8,7 \%)$ \\
\hline
\end{tabular}

* Dane wyrażające stosunek liczby czasowników/zaimków do ogólnej liczby tokenów w korpusie. Pozostałe dane liczbowe odnoszą się do odsetka czasowników lub zaimków.

Źródto: opracowanie własne. 


\section{Bibliografia}

Appelbaum Paul S. (1997) A theory of ethics for forensic psychiatry. "The Journal of the American Academy of Psychiatry and the Law", vol. 25, no. 3, s. 233-247.

Atkinson J. Maxwell, Drew Paul (1979) Order in Court. Houndmills: Macmillan.

Baker Paul (2006) Using Corpora in Discourse Analysis. London: Continuum.

Barbaro de Bogdan (2014) Dylemat psychiatrii: "zły czy szalony”. „Psychiatria. Pismo dla Praktyków”, nr 7, s. 14.

Beck Urlich, Lau Christoph (2005) Second modernity as a research agenda: theoretical and empirical explorations in the 'meta-change' of modern society. „The British Journal of Sociology", vol. 56, no. 4, s. 525-557.

Bhatia Vijay K. (1987) Textual-mapping in British legislative writing. „World Englishes”, vol. 6, no. 1, s. 1-10.

Bilikiewicz Adam (2006) Psychiatria. Podręcznik dla studentów medycyny. Warszawa: PZWL.

Bolechała Filip (2009) Stan psychiczny a odpowiedzialność karna - regulacje prawne i kryteria medyczne w Polsce oraz innych państwach. „Archiwum Medycyny Sądowej i Kryminologii”, nr 54, s. 309-319.

Boltanski Luc (2014) Mysteries and Conspiracies. Detective Stories, Spy Novels and the Making of Modern Societies. Przełożyła Catherine Porter. Cambridge: Polity.

Brezina Vaclav, McEnery Tony, Wattam Stephen (2015) Collocations in context. "International Journal of Corpus Linguistics", vol. 20, no. 2, s. 139-173.

Brezina Vaclav, Timperley Matthew, McEnery Anthony (2018) \#LancsBox v. 4.x. [dostęp 30 września 2020 r.] Dostępny w Internecie: http://www.research.lancs.ac.uk/portal/en/publications/lancsbox-v-4x(b03e99c8-7e4e-4915-927e-ef56a9999c5e)/export.html.

Buchanan Alec (2006) Psychiatric evidence on the ultimate issue. "The Journal of the American Academy of Psychiatry and the Law", vol. 34, no. 1, s. 14-21.

Candilis Philip J. (2009) The Revolution in Forensic Ethics: Narrative, Compassion, and a Robust Professionalism. „The Psychiatric clinics of North America", vol. 32, no. 2, s. 423-435.
Candilis Philip J., Martinez Richard, Dording Christina (2001) Principles and narrative in forensic psychiatry: toward a robust view of professional role. „The Journal of the American Academy of Psychiatry and the Law", vol. 29, no. 2, s. 167-173.

Candilis Philip J., Weinstock Robert, Martinez Richard (2007) Forensic Ethics and the Expert Witness. New York: Springer.

Creswell John W. (2003) Research Design: Qualitative, Quantitative, and Mixed Methods Approaches. Thousand Oaks, CA: Sage.

Foucault Michel (1988) Gry władzy. Rozmowa z Michelem Foucaultem. Przełożył Tadeusz Komendant. „Literatura na Świecie”, nr 6.

Foucault Michel (1993) Nadzorować i karać. Przełożył Tadeusz Komendant. Warszawa: Spacja.

Foucault Michel (2002) Morderstwa, o których głośno [w:] Michel Foucault, red., Ja, Piotr Riviere, skorom już zaszlachtowat moja matke, moja siostre i brata mojego... Przypadek matkobójcy z XIX wieku. Przełożył Tadeusz Komendant. Gdańsk: słowo/obraz terytoria, s. 221-230.

Foucault Michel (2018) Zło czynić, mówić prawdę. Funkcja wyznania w sprawiedliwości. Wykłady z Louvain, 1981. Przełożył Andrzej Zawadzki. Kraków: Znak.

Galdia Marcus (2017) Lectures on Legal Linguistics. Frankfurt a. M.: P. Lang.

Garfinkel Harold (1967) Studies in Ethnomethodology. Englewood Cliffs, NJ: Prentice Hall.

Gierowski Józef K. (2003) Psychiatria sadowa w Polsce - aktualny stan i perspektywy. „Palestra”, nr 48/7-8, s. 104-120.

Gierowski Józef K. (2006) Przedmowa [w:] Lech K. Paprzycki, red., Opiniowanie psychiatryczne i psychologiczne w procesie karnym: orzecznictwo i piśmiennictwo. Kraków: Instytut Ekspertyz Sądowych, s. 17-26.

Gierowski Józef K. (2014) Na pograniczu prawa i psychiatrii - zakresy wspótpracy i kontrowersji [w:] Bogdan de Barbaro, red., Konteksty psychiatrii. Kraków: Wydawnictwo Uniwersytetu Jagiellońskiego, s. 165-171.

Giorgi-Guarnieri Deborah i in. (2002) AAPL practice guideline for forensic psychiatric evaluation of defendants raising the insanity 
defense. "The Journal of the American Academy of Psychiatry and the Law", vol. 30 (suppl), s. 1-20.

Górnicz Mariusz (2011) Tłumaczenie kart informacyjnych leczenia szpitalnego na język angielski. „Lingua Legis”, t. 19, s. 63-69.

Griffith Ezra E. H., Baranoski Madelon (2007) Commentary: The place of performative writing in forensic psychiatry. „The Journal of the American Academy of Psychiatry and the Law", vol. 35, no. 1, s. 27-31.

Griffith Ezra E. H., Stankovic Aleksandra, Baranoski Madelon (2010) Conceptualizing the Forensic Psychiatry Report as Performative Narrative. „The Journal of the American Academy of Psychiatry and the Law", vol. 38, no. 1, s. 32-42.

Griffith Ezra E. H., Stankovic Aleksandra, Baranoski Madelon (2011) Writing a Narrative [w:] Alec Buchanan, Michael A. Norko, eds., The Psychiatric Report: Principles and Practice of Forensic Writing. New York: Cambridge University Press, s. 68-80.

Habzda-Siwek Ewa (2006) Opinia o stanie zdrowia psychicznego oskarżonego: aktualne problemy. "Czasopismo Prawa Karnego i Nauk Penalnych", t. 10, nr 2, s. 175-197.

Hajdukiewicz Danuta (2016) Zagadnienia psychiatrii sadowej cz. 1 - podstawy prawne i medyczne. Warszawa: IPiN.

Heffer Chris (2005) The Language of Jury Trial: A Corpus-Aided Analysis of Legal-Lay Discourse. Basingstoke: Palgrave Macmillan.

Kacperska Iwona i in. (2016) Reliability of repeated forensic evaluations of legal sanity. „International Journal of Law and Psychiatry", vol. 44, s. 24-29.

Kamasa Victoria (2014) Techniki językoznawstwa korpusowego wykorzystywane w krytycznej analizie dyskursu. Przeglad. „Przegląd Socjologii Jakościowej", t. 10, nr 2, s. 100-117.

Kennedy Graeme (1998) An Introduction to Corpus Linguistic. London: Longman.

Krakowiak Damian (2018) Sprawca niepoczytalny w procesie karnym. Łódź: Wydawnictwo Uniwersytetu Łódzkiego.

Legendre Pierre (2011) Zbrodnia kaprala Lortiego. Traktat o Ojcu. Przełożyła Anastazja Dwulit. Warszawa: Fundacja Augusta hr. Cieszkowskiego, Biblioteka kwartalnika KRONOS.

Martinez Richard, Candilis Philip J. (2005) Commentary: Toward a Unified Theory of Personal and Professional Ethics. „The journal of the American Academy of Psychiatry and the Law", vol. 33, no. 3, s. 382-385.

Marton Zbigniew (1990) Wstęp do psychologii sądowej. Katowice: Wydawnictwo Uniwersytetu Śląskiego.

Matoesian Gregory M. (1993) Reproducing Rape: Domination through Talk in the Courtroom. Chicago: University of Chicago Press.

Meynen Gerben (2016) Legal Insanity. Explorations in Psychiatry, Law, E Ethics. New York: Springer.

Miller Don, Biber Douglas (2015) Evaluating reliability in quantitative vocabulary studies: The influence of corpus design and composition. „International Journal of Corpus Linguistics”, vol. 20, no. 1 , s. 30-53.

Mullen Paul E. (2010) The Psychiatric Expert Witness in the Criminal Justice System. "Criminal Behaviour and Mental Health", vol. 20, no. 3, s. 165-176.

O'Grady John (2004) Report writing for the criminal court. „Psychiatry", vol. 3, s. 34-36.

Paprzycki Lech K. (2011) Problematyka psychiatryczna i psychologiczna w prawie i postępowaniu karnym : granice kompetencji biegłych i organów procesowych. „Chowanna”, nr 2, s. 99-130.

Pardo Michael S., Patterson Dennis (2013) Minds, Brains, and Law: The Conceptual Foundations of Law and Neuroscience. New York: Oxford University Press.

Pawlikowska Aleksandra (2012) Zastosowanie metod jezykoznawstwa korpusowego i lingwistyki kwantytatywnej w analizie dyskursu. „Oblicza Komunikacji”, nr 5, s. 111-125.

Pennebaker James W. (2011) The Secret Life of Pronouns: What Our Words Say About Us. New York: Bloomsbury Press.

Piasecki Maciej, Walkowiak Tomasz, Maryl Maciej (b.d.) Literary Exploration Machine: A New Tool for Distant Readers of Polish Literature [dostęp 1 października 2019 r.]. Dostępny w Internecie: ‘ttps://dh2017.adho.org/abstracts/526/526.pdf».

Pobocha Jerzy (2010) Opiniowanie w zaburzeniach psychicznych - błędy i trudności. „Orzecznictwo Lekarskie”, t. 7, nr 1, s. 50-60.

Pobocha Jerzy (2013) Problemy etyczne orzecznictwa lekarskiego i psychiatrii sadowej [w:] Anna Wilmowska-Pietruszyńska, red., Opiniodawstwo sadowo-lekarskie. Wrocław: Elsevier, s. 182-190. 
Pużyński Stanisław (2007) Choroba psychiczna - problemy $z$ definicja oraz miejscem $w$ diagnostyce $i$ regulacjach prawnych. „Psychiatria Polska”, t. 41, nr 3, s. 299-308.

Pyrcak Małgorzata (2010) Opinie sadowo - psychiatryczne przy orzekaniu środka zabezpieczającego z art. 94 k.k. - analiza pod względem formalnym. "Internetowy Przegląd Prawniczy TBSP UJ", t. 1, nr 4, s. 65-74.

Resnick Philip J., Soliman Sherif (2011) Draftsmanship [w:] Alec Buchanan, Michael A. Norko, eds., The Psychiatric Report: Principles and Practice of Forensic Writing. New York: Cambridge University Press, s. 81-92.

Roth Walton T., Dager Stephen R. (2014) Psychiatry on trial: the Norway 2011 massacre. "The Journal Of Nervous And Mental Disease", vol. 202, no. 3, s. 181-185.

Rzeszutko Małgorzata (2003) Rozprawa sadowa w świetle lingwistyki tekstu. Lublin: Wydawnictwo Uniwersytetu Marii Curie-Skłodowskiej.

Samuels Anthony, O'Driscoll Colman, Allnutt Stephen (2007) When killing isn't murder: psychiatric and psychological defences to murder when the insanity defence is not applicable. „Australasian Psychiatry", vol. 15, no. 6, s. 474-479.

Sinclair John (1991) Corpus, Concordance, Collocation. Oxford: Oxford University Press.

Sinclair John (2003) Reading Concordances: An Introduction. London: Longman.

Sinclair John (2004) Trust the Text. Language, corpus and discourse. London: Routledge.

Sinnott-Armstrong Walter, Levy Ken (2011) Insanity Defenses [w:] John Deigh, David Dolinko, eds., The Oxford Handbook of Philosophy of Criminal Law. New York: Oxford University Press, s. 229-334.

Stanik Jan (1980) Formy pracy i zakres zadań biegłego sąowego psychologa [w:] Wilhelmina Wosińska, red., Psychologiczne problemy funkcjonowania człowieka w sytuacji pracy. Katowice: Wydawnictwo Uniwersytetu Śląskiego.

Stone Alan (1984) Law, Psychiatry, and Morality Essays and Analysis. Washington: American Psychiatric Press.
Szafrański Tomasz (2014) Breivik i kryzys psychiatrii. „Psychiatria. Pismo dla Praktyków", nr 7, s. 9.

Szmukler George (2014) When psychiatric diagnosis becomes an overworked tool. „Journal of Medical Ethics” , vol. 40, no. 8, s. 517-520.

Tashakkori Abbas, Teddlie Charles (2003) Handbook of Mixed Methods in Social and Behavioral Research. Thousand Oaks, CA: Sage.

Tietze Tad (2014) The Breivik controversy: politics, terrorism and psychiatry. "Australasian Psychiatry: Bulletin Of Royal Australian And New Zealand College Of Psychiatrists", vol. 22, no. 4 , s. 383-385.

Van Leeuwen Evert, Kimsma Gerrit K. (1997) Philosophy of medical practice: a discursive approach. „Theoretical Medicine”, vol. 18 , s. $99-112$.

Verde Alfredo i in. (2006) The Narrative Structure of Psychiatric Reports. "International Journal of Law and Psychiatry”, vol. 29 , no. 1, s. 1-12.

Walkowiak Tomasz (2017) Language Processing Modelling Notation - Orchestration of NLP Microservices [w:] W. Zamojski i in., eds., Advances in Dependability Engineering of Complex Systems: Proceedings of the Twelfth International Conference on Dependability and Complex Systems DepCoS-RELCOMEX. Springer International Publishing, s. 464-473.

Woliński Marcin (2019) Morfeusz 2. Dokumentacja techniczna i użytkowa [dostęp 17 lipca 2020 r.]. Dostępny w Internecie: 〈http://download.sgjp.pl/morfeusz/Morfeusz2.pdf〉.

Wolska Anna (1998) Język sadowych orzeczeń psychologicznych w sprawach karnych dorostych [w:] Teresa Rzepa, red., O języku i komunikowaniu się. Szczecin: Uniwersytet Szczeciński, s. $93-104$.

Zaśko-Zielińska Monika (2013) Listy pożegnalne: w poszukiwaniu lingwistycznych wyznaczników autentyczności tekstu. Wrocław: Wydawnictwo Quaestio.

Zozula Daria (2019) Features of the language of law: A comparative study of Polish, English and Indonesian legal texts. „International Journal of Legal Discourse”, vol. 4, no. 1, s. 69-86. 


\title{
Cytowanie
}

Karlińska Agnieszka (2020) (Nie)przekładalność języków. Analiza korpusowa opinii sądowo-psychiatrycznych. „Przegląd Socjologii Jakościowej", t. 16, nr 4, s. 104-125 [dostęp dzień, miesiąc, rok]. Dostępny w Internecie: ‘www.przegladsocjologiijakosciowej. org . DOI: http://dx.doi.org/10.18778/1733-8069.16.4.06

\section{The (Un)Translatability of Languages: A Corpus Analysis of Forensic Psychiatric Reports}

\begin{abstract}
The paper presents challenges faced by psychiatrists who venture into the justice system. Based on the analysis of sixty-five forensic psychiatric reports, strategies assumed by expert witnesses in order to reconcile the language of medicine with the language of law were reconstructed. Methods and tools of corpus linguistics were used, such as: frequency lists, keyword analysis, and concordance analysis. The results indicate that forensic psychiatrists have difficulty in translating the language of medicine into the language of law. They use lexis and linguistic structures characteristic of medical genres, while appropriating legal vocabulary in the form of phrases drawn from the criminal code. The tensions resulting from the collision of the legal and the psychiatric discourse have been described in terms of the clash of two types of logic: "either/or", typical of the justice system, and "both/and", prevalent in contemporary clinical psychiatry. This analysis has also captured ethical challenges which stem from the double role of forensic psychiatrists as doctors and as representatives of the criminal justice system. It has shown that psychiatrists focused on playing the latter role, situating themselves on the side of the law.
\end{abstract}

Keywords: forensic psychiatry, forensic psychiatric reports, corpus analysis, keyword analysis, concordance analysis 